\title{
Ultrasonic Testing of Girth Welded Joint with TOFD and Phased Array
}

Daniel Dopjera, Radoslav Koňár, Miloš Mičian

University of Žilina, Faculty of Mechanical Engineering, Department of Technological Engineering. Univerzitná 1,010 26 Žilina. Slovakia. E-mail: daniel.dopjera@fstroj.uniza.sk, radoslav.konar@fstroj.uniza.sk, milos.mician@fstroj.uniza.sk

The article describes the fundamental physical principles of the ultrasonic defectoscopy TOFD (Time of Flight Diffraction) and Phased Array. There is a report from the ultrasonic testing of girth welded joint with ultrasonic flaw detector OmniScan MX2 16:64 PA from the company Olympus NDT. In welded joint were artificaly made three defetcts. Two lack of sidewall fusion (on the left and right side of welded joint) and one crack in axis of welded joint. Both ultrasonic testing were designed in software ESBeamTool 5 from the company Eclipse Scientific, which simulates the geometrical ultrasonic beams spread. At the end, data from both ultrasonic testing were evaluated. The same procedure will be used for the design of ultrasonic inspection TOFD and Phased Array at girth welded joints of gas pipelines.

Keywords: NDT, Ultrasonic testing, TOFD, Phased Array

\section{Acknowledgement}

This article was created within the project solution no. 561/PG04/2011, which is supported by non-profit fund EkoFond, which founder is joint stock company SPP.

\section{References}

[1] ANDROŠOVÁ, Z., SKRBEK, B. (2012). The use of magnetic and ultrasonic structuroscopy for inspection of ADI/AGI castings. In: Manufacturing technology, Vol. 12, No. 13, pp. 93-97. ISSN 1213-2489.

[2] MEŠKO, J., et al. (2011). Shape of heat source in simulation program SYSWELD using different types of gases and welding methods. In: Strojírenská technologie. Vol. 16, No. 5, pp. 6-11. ISSN 1211-4162.

[3] NOVÁK, P., MEŠKO, J., ŽMINDÁK, M. (2011). Finite element implementation of multi-pass fillet weld with phase changes. In: Manufacturing technology, Vol. 13, No.1, pp.79-85. ISSN 1213-2489.

[4] OLYMPUS. (2013). The company Olympus NDT. [Online]. 2013, [cit. 2013-08-18]. Internet: <http://www.olympus-ims.com/cs>.

[5] OLYMPUS. (2013). Phased Array Tutorial. [Online]. 2013, [cit. 2013-08-18]. Internet: <http://www.olympus$\mathrm{ims.com/cs/ndt-tutorials/phased-array>.}$

[6] OLYMPUS. (2012). Phased Array Testing Basic Theory for Industrial Applications. 2nd ed. Waltham, MA: Olympus NDT, 2012. 113 pp. DMTA-20003-01EN.

[7] OLYMPUS. (2007). Advances in Phased Array Ultrasonic Technology Applications. Waltham, MA: Olympus NDT, 2007. 491 pp. ISBN 0-9735933-4-2.

[8] OLYMPUS. (2004). Introduction to Phased Array Ultrasonic Technology Applications. Waltham, MA: Olympus NDT, 2004. 351 pp. ISBN 0-9735933-0-X.

[9] SKRBEK, B., et al. (2012). Verification of Modification Effect on Prototype Castings from GJV Using Ultrasound Checking. In: Archives of Foundry Engineering. Vol. 12, No. 3, pp. 103-108. ISSN 1897-3310.

[10] TEMBLAY, P. - RICHARD. D. (2013). Development and validation of a full matrix capture solution. [Online]. 2013, [cit. 2013-11-02]. Internet: <http://www.ndt.net/article/jrc-nde2012/papers/79.pdf>.

[11] ŽMINDÁK, M., et al. (2014). Finite element analysis of crack growth in pipelines. In: Manufacutirn Technology, Vol. 14., No. 1, pp. 116-122. ISSN 1213-2489. 